\title{
How European Union Membership Can Undermine the Rule of Law in Emerging Democracies
}

\author{
Jonathan B. Slapin
}

Word Count (excluding title page): 9200 words

\begin{abstract}
The European Union (EU) considers the spread of economic prosperity and rule of law to countries emerging from dictatorship among its primary goals when considering countries as candidates for membership. Existing literature often suggests that EU membership confers significant benefits on the accession countries, and these countries are willing to undergo costly and difficult reforms to reap these benefits. Through strict membership conditions, member states force accession countries to commit to democracy. Drawing on theoretical work in the fields of law, politics and economics, this article reassesses the conventional wisdom. It argues that, under certain conditions, the reforms required of would-be members could have the perverse effect of undermining the establishment of legitimate law in transitional democracies. Using an agent-based model, the article elucidates a theory in which placing laws on the books around which no societal consensus exists can create perverse incentives for citizens and government officials and may lead to an erosion of the rule of law.
\end{abstract}

Keywords: European Union; Enlargement; Rule of Law; Transitional Democracies; Implementation; Agent-Based Model

Author Bio: Jonathan B. Slapin is Associate Professor of Political Science and Director of the Center for International and Comparative Studies at the University of Houston. He is co-author of The Politics of Parliamentary Debate: Parties, Rebels, Representation (Cambridge University Press, 2015) and author of Veto Power: Institutional Design in the European Union (University of Michigan Press, 2011). He has published numerous articles on European politics, European integration, political institutions and research methods.

Author Correspondence: jslapin@uh.edu 
The European Union (EU) considers the spread of economic prosperity and rule of law to countries emerging from authoritarian rule among its primary goals when considering candidates for membership. Likewise, scholars and policymakers argue that the "carrot" of potential EU membership encourages newly democratizing countries to cement their transition. EU scholars often suggest that the possibility of membership helped push the governments of Greece, Portugal, and Spain to ensure the success of their democratic transitions in the 1970s (Whitehead 2001). In the early 1990s, many policymakers, including Germany's Chancellor Helmut Kohl, felt it was in the best interest of both EU members and post-communist countries to ensure a clear, quick path to membership for countries emerging from the Soviet sphere of influence (Vachudova 2005: 97). Such arguments are more recently made with regard to EU expansion to the Balkans and Turkey. ${ }^{1}$ The argument suggests that EU membership confers significant benefits on accession countries and these countries are willing to undergo costly and difficult reforms to reap these benefits. Through strict membership conditions, member states force accession countries to commit to the rule of law. The standard argument, however, downplays the difficulties accession countries face in implementing the changes required of them.

Using an agent-based model, this article offers a new theoretical argument that reassesses the conventional logic behind enlargement. Because the potential benefits of membership in the EU are so attractive to transitional governments, and because these governments fear dire consequences should they not be granted membership, they may agree to drastic reforms or pass laws as a condition of membership that they will find

\footnotetext{
1 “Europe: The End of Enlargement?” The Economist July 16, 2005, pg. 38.
} 
difficult to implement. When societal consensus does not already exist around the social norms that underpin EU law(e.g. workers' rights or envirenmental protection), or citizens cannot adequately assess the existence of consensus, international pressure may create perverse incentives for governments to draft laws that both they and their citizens have no intention of obeying. The existence of such laws, and the lack of observable compliance with them, advertise to politicians, bureaucrats and citizens alike that secietat consensus regarding the norms underpinning these laws does not exist. Ithat they mayt is safely to-ignore laws based on these norms. Rather than fostering new societal consensus, these laws undermine the ability of law to shape behavior and reveal that it is acceptable to write laws only to violate them.

The article first reviews the literature on EU enlargement and implementation. It then introduces a new theory to understand when and why the "carrot" of EU membership may actually undermine the rule of law. The model lays out the conditions under which the existence of laws that are not enforced or are regularly violated can erode beliefs about societal support for other laws. By examining transposition, implementation, and infringement records of new and old EU member states, including a case study of Lithuania, the article provides preliminary empirical evidence that these conditions exist in the post-communist EU member states.

\section{EU Enlargement and Transitions to Democracy}

Much work on EU enlargement is premised on the notion that enlargement provides transitional governments with incentives to reform (Schimmelfennig 2005; 
Schimmelfennig and Scholtz 2008; Vachudova 2005). And many have argued that the EU has been highly successful in helping transform previously authoritarian countries to democracy (e.g. Hafner-Burton 2005). More normatively, scholars state that the EU should commit to promoting democracy in central and eastern Europe (Zielonka 2004). Vachudova (2005), in particular, has convincingly demonstrated the positive effects of EU leverage in the run-up to eastern enlargement.

Studies of enlargement, though, often ponder why the EU's "transformative" power was not greater given the tools at its disposal (Grabbe 2006), lament that EU was not more successful in influencing new member behavior (Conant 2014), or seek to understand when the EU most effectively transferred its norms to accession states (Schimmelfennig and Sedelmeier 2004). Even scholars who see adaption of EU's acquis communautaire as having strengthened state institutions in accession countries acknowledge the weaker impact that accession has had on civil society (Börzel 2010). Some have suggested that central and eastern European politicians were more interested in the economic and security benefits of membership, and treated democratic conditionality as an afterthought (Pridham 2005). Lastly, scholars who highlight the transformative nature of the enlargement process also describe "backsliding" after accession, once the EU can no longer hold out the carrot of membership (Vachudova 2008).

Prior to enlargement, many scholars did worry that the process would be rocky and would not necessarily lead to the benefits that many suggested would follow (e.g. Jacoby 1999; Grzymala-Busse and Innes 2003; Cameron 2003). Adopting the acquis is a substantial task for any democracy, involving the incorporation into national law of 
countless of pages of EU law governing everything from the size of chicken coops to carbon emissions trading schemes. Grzymala-Busse and Innes (2003: 66) argue that, "the effort to plough through reform blueprints...resembles a form of dependent development, to the point of precluding the 'organic' development of accountable domestic politics." Likewise, Cameron (2003: 25) writes that, “....upon accession, the new members were recreated as states, committed to processes of policymaking and policy outcomes that in many instances bear little or no relation to their prior domestic policymaking processes and policy decisions, but reflect, instead, the politics, policymaking processes, and policy choices of the EU and its earlier member states." Ekiert (2008: 20) points out that "effective implementation of the acquis depends not only on the administrative capacity of a state but also the degree to which the new values, rules, and practices being propounded are internalized by state functionaries and citizens." Along these lines, Goetz (2000) and Dimitrova (2002) express concerns that levels of governance, administrative reform, and the functioning of bureaucracy in Eastern Europe would not necessarily adapt merely through the act of accession.

These scholars argue that the EU's rules imposed from above may not function as organically produced rules would, especially when bureaucrats and citizens are not prepared to accept the values enshrined in the laws. Moreover, this EU literature comports with general work in the area of law and economics, suggesting that transposed law does not work as organic law does (Berkowitz et al. 2003; Pistor 2002) and could even have pernicious effects to the extent that it crowds out domestic democratic processes (Frey 1997). 
However, most literature on the potential harms of enlargement focuses on why existing member states might not desire it: more competition from cheap labor countries (Schneider 2009), more policy gridlock (König and Bräuninger 2004), and more difficulties when revising treaties (Finke et al. 2012; Slapin 2008, 2011). Quantitative studies examining the behavior of new members find that they transpose and comply with EU law at rates similar to older member states (Steuenberg and Toshkov 2009; Sedelmeier 2012). However, qualitative studies talk of a "world of dead letters" (Falkner et al. 2008). New member states transpose laws, but fail to actively enforce them. Falkner et al. argue that implementation rates look similar not because new member states actually implement EU laws, but because without an adequate legal culture, citizens and bureaucrats do not alert governments (or the Commission and ECJ) to potential problems with implementation.

\section{A Theory of Law, Focal Points, and Compliance}

The literature tends to focus on the positive effect of EU leverage in the lead-up to accession, but less has been written about the effects of implementing the acquis afterwards. Some scholars have hinted at possible negative effects of transposing such a large corpus of law, but there has been little theorizing about when and why such legal transposition improves the rule of law and when it may have the opposite effect. We lay out the conditions under which the carrot of EU membership may entice a candidate country to develop institutions and a legal culture that value adherence to law; but importantly, we determine the conditions under which the opposite may occur. 


\section{The Rule of Law and Compliance}

The first step in outlining the theory is to set out a definition of "rule of law". The concept of rule of law is difficult to pin down and it means different things to different scholars. For the purpose of this article, though, the rule of law refers to a general adherence to law on the books, a definition closely related to implementation. When law is implemented appropriately (and complied with), the rule of law prevails. ${ }^{2}$ Some may take issue with this definition. For example, many would say that effectively implemented laws that undermine minority rights also undermine the rule of law. Certainly, such laws can have very detrimental effects for democracy. However, this article is more concerned with obedience to existing law, the logic being that if citizens have no intention to follow written law, it becomes meaningless.

In addition, we must discuss why individuals comply with law. We view law as providing a focal point - a point of reference that shapes individual behavior (Schelling 1960; McAdams 2000; Cooter 1998; Kelemen and Teo 2014). But why do people allow a focal point to impact their behavior, especially when doing so could be costly? In instances of coordination, adherence to law is trivial because obedience is virtually costless, and the benefits are great - e.g. driving on the right side of the road. But in other instances, where the costs are higher, compliance must be explained. Why do dog owners bother to clean up after their dog when no one is in the park? Or why does a bureaucrat implement a law she does not agree with? One line of reasoning could be that compliance is due to fear of punishment (Gibbs 1975; Tittle 1980). However, often the

\footnotetext{
${ }^{2}$ Many definitions of the rule of law are broader than this, and closely related to notions of democracy, freedom, justice, economic prosperity, and institutions such as separation of powers. For a more complete discussion, see Rodriquez et al. (2010).
} 
chance of getting caught is low and penalties are small. Instead, people are willing to conform to a focal point only when "moral authority" backs up the law in question or a social norm exists (Knight 1998; Sunstein 1996). Society agrees with the underlying premise of the law and is willing to incur costs to comply with it in order to fulfill their civic obligation. Individuals comply because they view the law as legitimate, where legitimacy is defined as existence of societal consensus (Tyler 2006).

When much of society does not agree with the premise of a law, it will not serve as a meaningful focal point — the ubiquity of speakeasies during the prohibition era in the United States provides a good example. Likewise, people curb their dog because they agree with the underlying notion that good citizens should be responsible pet owners and they value clean parks. This does not imply that the law is meaningless - without signs drawing citizens' attention to the fact that they ought to clean up after their dog they would not do it even if they held similar values for a clean parks. The law (or the sign advertising the existence of the law) creates a focal point; it informs citizens that other like-minded dog owners are aware of the law and will likely pick up after their pet, as well. This notion of law and compliance means that simply drafting new laws (and putting up new signs) is not enough to ensure that they work. The city of Paris, for example, has plenty of signs drawing dog owners' attention to the $€ 500$ fine for failing to clean up after their pooch. Needless to say, the signs do little good - societal consensus around curbing one's dog does not exist in Paris.

Lastly, we must discuss the effects of having laws on the books around which no societal consensus exists. One may view such laws as relatively benign. Little is gained by having them on the books, but little is lost. However, others have argued that a law not 
supported by civic attitudes, and thus not obeyed, can have negative consequences, especially in transitional democracies (Pistor 2002). Such illegitimate laws may undermine the rule of law in several ways. First, when citizens and bureaucrats see that they can routinely ignore (or fail to properly implement) law with few consequences, the perceived cost for non-compliance with all law may be reduced. Of course, if the threat of punishment does not matter for compliance to begin with then this argument may not hold. Second, illegitimate law may lead individuals to find creative ways to formally observe the law while violating it in spirit, an act dubbed "creative compliance" (McBarnet and Whelan 1991). Once individuals realize they can avoid true compliance in one arena they may do so in another, breeding a culture in which creative compliance is acceptable. Lastly, the presence of illegitimate laws may reduce the extent to which an individual's disobedience sends a signal to others about an individual's latent propensity for law-breaking (Posner 2000).

While these arguments apply to all countries, the problems associated with having illegitimate law on the books are amplified in transitional democracies, where the meaning of law is often less clear, the level of legal clarity is lower, and bureaucrats are less accustomed to implementing law in a non-political manner (Nonet and Selznick 2001; Linz and Stepan 1996: 14, 248-252). In full democracies, the cost of a having a small number of (often minor) laws that some citizens and bureaucrats routinely ignore is relatively low. In transitional democracies, though, the effects are likely greater. The ratio of illegitimate law to legitimate law may be much higher than in fully-fledged democracies. Moreover, both bureaucrats and citizens are in the process of learning what 
it means to live in a society under the rule of law. When law is flouted in these early stages, the consequences are likely much greater.

\section{The Model}

To understand the conditions under which new law creates a focal point and leads to compliance, we present an agent-based model. In the model actors' beliefs about the existence of societal consensus influence their decision to comply. Actors could be bureaucrats, who learn whether consensus exists when deciding whether to properly implement and enforce the law, or citizens, who must decide whether to obey.

In the model, a law $L$ exists which each of $n$ actors may or may not support. Individual views regarding support for the law are private information. A societal consensus around the legitimacy of the law exists if a sufficiently high proportion of actors, $t$, supports $L$. As actors do not know how others view $L$, they cannot know if societal consensus exists. However, they do hold an initial belief about others' views, and therefore about the existence of consensus. Before observing any compliance behavior, they believe that each actor supports the law with probability $p$. We will assume that $p$ is constant across all actors. Actors always comply with law they support when they believe that society also considers the law legitimate. With probability $r$, actors comply with law they support but they believe society does not consider legitimate. With probability $q$, actors comply if they believe that society finds the law legitimate but they do not support it. And lastly, actors never comply with a law that they do not support and do not believe society supports. Thus, while the underlying true support for the law is unknown, the probabilities $p, r$ and $q$, as well as the threshold for consensus, $t$, are common knowledge. 
With these parameter values in mind, each actor simultaneously observes whether the other actors obey the law. Upon observing compliance behavior, all actors update their beliefs about each actors' support for the law using Bayes' rule. With this information, they can update their beliefs about the existence of societal consensus. Specifically, they update their beliefs regarding the probability that an individual supports the law given that she has complied with the law as follows:

$\operatorname{pr}($ support $\mid$ compliance $)=\frac{\operatorname{pr}(\text { compliance } \mid \text { support }) * \operatorname{pr}(\text { support })}{\operatorname{pr}(\text { compliance })}$

where,

$\operatorname{pr}($ compliance $\mid$ support $)=1-F(t * n ; n, p)+r * F(t * n ; n, p)$

$\operatorname{pr}($ support $)=p$

$\operatorname{pr}($ compliance $)$

$$
\begin{aligned}
& =p *[1-F(t * n ; n, p)+r * F(t * n ; n, p)]+(1-p)[q *(1-F(t \\
& * n ; n, p))]
\end{aligned}
$$

and the function $\mathrm{F}(\square)$ represents the CDF of the binomial distribution. Thus, the numerator in equation 1 is the probability that an individual complies with the law given that she supports the law, multiplied by the prior belief that each individual supports the law, $p$. The probability of compliance given support is the probability that society views the law as legitimate (the probability that at least $t * n$ citizens support the law) plus the probability that society does not view the law as legitimate multiplied by $r$. The denominator is the probability of compliance regardless of support.

Likewise, actors can calculate the probability of an individual's support given non-compliance:

$\operatorname{pr}($ support $\mid$ noncompliance $)=\frac{\operatorname{pr}(\text { noncompliance } \mid \text { support }) * \operatorname{pr}(\text { support })}{\operatorname{pr}(\text { noncompliance })}$ 
where

$\operatorname{pr}($ noncompliance $\mid$ support $)=(1-r) F(t * n ; n, p)$

$\operatorname{pr}($ support $)=p$

$\operatorname{pr}($ noncompliance $)=p(1-r) F(t * n ; n, p)+(1-p)[(1-q)(1-F(t * n ; n, p))+$ $F(t * n ; n, p)]$

After viewing compliance behavior, actors calculate the probability that all other actors support the law using equations 1 and 2 . By averaging the newly calculated probabilities of support over the population, actors arrive at a new belief about the probability, $p$, that any given individual supports the law. They then use this new value as their prior belief about $p$ when evaluating any similar new law that is passed. Thus, compliance behavior on one law affects beliefs regarding consensus on future laws.

To demonstrate how societal support for law may be sustained or may erode we examine compliance behavior for three different scenarios of initial underlying population support over a number of rounds. We observe compliance after 100 rounds when $90 \%$ of the population initially supports the law, 50\% supports, and $10 \%$ supports. We specify a fixed threshold for a societal norm to exist, $t=0.75$, and we assume a population of $n=40$, perhaps the size of a small community of individuals who interact and observe each other's behavior with sufficient regularity. We then examine compliance outcomes for all parameter value combinations for the remaining parameters $-p, q$, and $r$. Initial model runs reveal that $\mathrm{q}$ has no impact on the proportion of the population that obeys when initial support is sufficiently high, and $r$ has no impact when initial support is sufficiently low. Thus, when running the model with initial support set to $90 \%, q$ is held at 0.5 , and when running the model with initial support at $10 \%, r$ is held 
at 0.5 . However, both matter when initial population support is moderate, and we vary both in this instance. ${ }^{3}$

To illustrate how the model works, imagine a government wishes to write new regulations in the area of environmental policy which $n$ bureaucrats are meant to implement (e.g. waste must be disposed of in a specific manner or new taxes to support recycling efforts are levied). The true initial support for new environmental regulations among the bureaucrats is $20 \%$, so that 8 individuals from our population of 40 support new regulations. This true level of support, however, is not known. Instead, each actor believes that the others support laws with probability $p=0.7-$ in other words, they greatly overestimate true support. The government then passes a law and all bureaucrats observe whether the others implement the law, a decision which is a function of each individual's true support as well as $p, q, r$ and $t$. Upon witnessing actors' behavior, beliefs about individual support, and thus $p$, are updated through equations 1 and 2 . The government then passes a second environmental regulation, the bureaucrats again witness whether their colleagues have implemented the law, and they again update beliefs. Depending upon the parameter values, beliefs about $p$ quickly converge on the true level of population support, or they do not, as we will demonstrate below.

First, we examine the scenario in which initial support in the population is $90 \%$, clearly above the threshold for societal consensus. The results are presented graphically in figure 1. The first panel presents a histogram of the percentage of the population obeying the law across all runs (2601 runs, each with a different value for $p$ and $r$ ). The second panel plots the proportion of the population obeying as a function of $p$ and $r$.

${ }^{3}$ Further runs have revealed that 100 rounds is sufficient to reach equilibrium. A stable state typically emerges after as few as six rounds. 
While the proportion obeying the law is often as high or higher than the true support in the population — above $90 \%$ — there are surprisingly many combinations of parameter values that lead compliance to collapse. For values of $r$ below approximately 0.4 and values of $p$ below the threshold for societal consensus 0.75 , the proportion of the population obeying the law is significantly less than the underlying level of true support. In other words, when people believe societal support for the law is significantly lower than it actually is, and they only wish to obey laws that society as a whole supports, compliance erodes quickly.

\section{INSERT FIGURE 1 ABOUT HERE}

Second, we examine instances in which true initial support for the law in population is low $-10 \%$. The results are shown in figure 2. As expected, for most parameter values, general compliance with the law fails to emerge. Nevertheless, even when population support is very low, for a small combination of parameter values, broad compliance can occur. It occurs when values for both $q$ and $p$ are both very high. In other words, when actors mistakenly think that broad support exists, and they feel societal views matter a great deal, compliance can emerge with little true underlying support. However, we should note that the range of parameter values that support compliance when true support is low is much smaller that the range of parameter values to lead to low compliance when true support is high.

INSERT FIGURE 2 ABOUT HERE 
Finally, we examine compliance when true support is middling $-50 \%$. Because both $q$ and $r$ matter in this scenario, we require three surface plots to fully characterize the relationship between $p, r, q$ and the proportion of the population obeying the law. Again, though, we see that compliance increases in $p, r$, and $q$. Moreover, there are combinations of parameter values that lead to a collapse in compliance (low $r$ and low $p$, low $q$ and low $r$ ), but also combinations that lead to near perfect compliance (namely high $p$ ). Overall, though, there are more combinations that lead to levels of compliance lower than the true support for the law than levels of compliance higher than the true support.

\section{INSERT FIGURE 3 ABOUT HERE}

These simulations illustrate the importance of individual views about societal consensus for compliance with the law. When individuals believe that societal consensus exists and they care about societal views, a new law can serve as a focal point and leads to compliance. Remarkably, compliance may occur even when true support has yet to develop, as can be seen in figure 2. Over time, this may lead to true support for laws as people form habits with regard to compliance and opinions change. However, if the importance of society decreases to more moderate levels, compliance quickly erodes. Moreover, even when true support for law is high, if views about society do not match the truth, compliance may fail to materialize. These theoretical findings suggest governments ought to carefully consider both societal support and the importance of civil society before writing new law.

\section{Implications for Emerging Democracies and Transposition of EU Law}


The model demonstrates suggests thatthe difficulty of generating compliance whenever social norms do not conform to the norms embedded in the law. Of course, such a discrepancy could occur both in EU15 member states (those states that were members prior to the 2004 enlargement round) as well as in post-Communist members. Moreover, variation in societal support for regulation in areas such as environmental protection and workers' rights, both areas where the EU legislates extensively, likely exists across the post-Communist member states as well as within the EU15 members. Nevertheless, we expect transitional democracies, on average, to find implementation may be-particularly difficult compared with the more established democracies of the EU15t in transitional democracies.

In countries emerging from long periods of authoritarian rule or Communist dictatorship, civil society may not exist to the extent it does in advanced industrialized democracies (e.g. Reisinger et al. 1995; Linz and Stepan 1996: 245). A lack of civil society reduces the likelihood of compliance in two ways. First, citizens and government officials may be more likely to misread the true support for law $p$. And second, the importance of societal attitudes for individual compliance behavior may be lower compared to the West, implying lower values for $q$ and $r$. Even if an individual supports a particular EU law, she may think others in society are less likely to support it, and she may think that society's views matter less for her own compliance on this issue. Unless the area of EU law under consideration already has reasonably high support within the population, introducing law without such support could quickly reveal that true support for legislation in this area is low. In other words, for the same level of societal support for
Formatted: Indent: First line: 1.27 $\mathrm{cm}$ 
a given societal norm, compliance should be more difficult in countries emerging from

Communism.

In many ways, EU expansion to newly transitioning democracies creates a perfect storm for the rule of law. The potential benefits of membership for transitional states are often too large to pass up. For example, almost overnight central and eastern European EU accession countries were able to borrow on international markets at practically German-level interest rates (Gray 2009). Thus, once given the option of membership, governments feel they must be included in an organization, rather than remain on the sidelines. Transition countries feel they must to do whatever it takes to become a member, including accepting great swathes of the acquis, which they may be unable to implement. Of course, in other instances, EU enlargement may provide an opportunity to solidify the rule of law. When latent public support is sufficiently high, the addition of EU law may create new focal points, and new social norms may quickly develop.

\section{Transposition and Implementation of EU Law in Post-}

\section{Communist Members: Some Evidence}

The primary contribution of this article is theoretical and a straightforward test of the micro-level foundations of the model is beyond its scope. Such a test would require data on individual beliefs about the legitimacy of particular laws, individual beliefs about what "society" as a whole thinks of these same laws, and evidence that these beliefs affect decisions to enforce and comply with both existing and new laws. No data exist that would allow for a large- $n$, cross-national investigation. Even if sufficient survey data did exist on attitudes towards laws, they would be less likely to capture compliance - 
respondents would be unlikely to confess to flouting the law. Instead, we derive some observable expectations regarding the transposition and implementation of EU law from the theory and provide evidence that the preconditions exist for the predictions of the model to hold.

The theory suggests that a gap between a government's willingness to accept EU law (e.g. correctly transpose directives) and the actual implementation of the law is both a necessary condition for enlargement to undermine the rule of law and preliminary evidence that it may be occurring (in terms of the formal model, $r, p$ and $q$ would be low, but the government must accept the EU law regardless). The theory also-suggests this gap should be larger in new member states where the difference between true societal support and individuals' beliefs, $p_{2}$ is likely larger and societal pressure when societal support does exist, $q_{2}$ is smallerless.-_Lastly, the theory suggests that rates of transposition of EU directives are not good proxies for implementation and adherence to EU law in transitional countries. If new member states are simply looking to please bureaucrats in Brussels, governments may transpose laws that they are unlikely (or unable) to enforce, and citizens are unlikely to obey. While it is difficult to examine whether the existence of one illegitimate law - i.e. a law that lacks sufficient societal support and, therefore, does not create a focal point - leads to more illegitimate laws, it is possible to examine whether post-communist transition countries are more likely to write illegitimate law than EU15 member states.

The model would also predict variation across newall member states to the extent that underlying societal attitudes vary cross-nationally. And there is substantial evidence that new member states do vary with respect to rule of law and human rights abuses 
(Conant 2014). Nevertheless, we have argued that there are likely fundamental differences between the effects of EU law in established democracies and new democracies even when underlying societal attitudes are the same. We begin by presenting aggregate level data comparing transposition in all post communist member states with EU15 member states. Then we present a brief case study of one particular post-communist country that is generally viewed as having made significant progressive towards greater democracy and rule of law - Lithuania.

Many post-communist transition countries are particularly good at transposing EU law and rapidly resolving disputes with the Commission, often better than EU15 states (Sedelmeier 2008; 2012). However, their success is likely due to fewer reported violations than in EU15 states despite underlying conditions that make violations more likely. We provide some evidence for this across issue areas, and then we focus on one particular area - labor law. The Commission breaks down infringement proceedings into three categories: those that arise as a result of the Commission's own initiative, those that result from citizen complaints to the Commission, and those due to a failure on the part of a member state to communicate the steps it has taken to transpose and implement EU law. ${ }^{4}$ When examining proceedings ongoing as of 31 December 2010 , the mean postcommunist state was involved in approximately 50 proceedings while the mean EU15 state was involved in 100, a highly statistically significant difference $(\mathrm{p}=0.0015)$. Moreover, post-communist countries are much faster to resolve infringements when discovered and compared with EU15 countries they rarely end up in court. Of all

\footnotetext{
${ }^{4}$ Data on infringement proceedings come from the Statistical Annexes I-III to the Report From the Commission, 28th Annual Report on Monitoring the Application of EU Law (2010). Com(2011)588 final, SEC(2011) 1093 final, available at http://ec.europa.eu/eu_law/infringements/infringements_annual_report_en.htm.
} 
infringement proceedings started in 2010, 53\% were still open at the end of the year in the average post-communist country compared with $70 \%$ in the average EU15 state. Between 2007 and 2011, the average EU15 member state faced 42 new infringement cases that made it as far as the European Court of Justice (ECJ), compared with only 11 for the average post-communist state.

However, these aggregate numbers mask some variation within the three categories. Among infringement cases arising as a result of the Commission's own initiative, the differences between the EU15 and post-communist states are less marked. In cases initiated in 2010, there is no statistical difference in the average number of cases per member state between EU15 and post-communist states. When examining cases ongoing at the end of the year, the post-communist countries are involved in somewhat fewer cases than EU15 states, but this is likely a result of post-communist countries' rapid resolution of infringement cases. Likewise, there is little difference in the number of cases resulting from member state failure to communicate steps taken to transpose EU law. The real differences occur in the number of cases arising from instances in which citizens or other actors complain to the Commission that the member state has failed to live up to its obligations under EU law. In the average post-communist member state, 12 infringement proceedings arose in this manner on average, compared with 48 in the average EU15 state, a highly statistically significant difference $(p=0.0007)$. In other words, the Commission is just as likely to find infringements in the EU15 and postcommunist states when it looks for them, but the Commission is much less likely to receive complaints regarding potential violations in the post-communist countries. Moreover, post-communist states land in the ECJ less often because courts in the post- 
communist states are significantly less likely to make use of preliminary references than EU15 courts. Between 2007 and 2011, courts in the average EU15 state requested 80 preliminary rulings, compared with only 20 from the average post-communist country. This may be due to citizens in post-communist countries bringing fewer court cases concerning EU law to national courts, national court judges seeking the opinion of the ECJ at lower rates, or a combination of both. ${ }^{5}$

These data suggest that new post-communist member states may stay out of court not because they are particularly good at implementing EU law, but rather because they are good at transposing it to the satisfaction of the Commission. ${ }^{6}$ Ideally, we would want to know if the states in which violations are most likely to occur are also the ones that generate the greatest number of infringements and ECJ cases. Unfortunately, it is very difficult to know a priori which states are most likely to violate a provision of EU law. For example, we may assume that gender discrimination is lowest in countries where allegations of unfair pay practices, sexual harassment, or domestic violence are lowest. However, such an assumption requires us to believe that women can report discrimination with equal ease and societal mores regarding gender and discrimination are the same across countries. If discrimination is more difficult to report (or not viewed as a problem) in countries where it is more prevalent, it entirely possible that there will be more discrimination cases in the countries with greater gender equality. In fact, we would expect a curvilinear relationship between true, latent levels of discrimination and

\footnotetext{
${ }^{5}$ Data on preliminary references come from the 2011 European Court of Justice Annual Report available at http://curia.europa.eu/jcms/jcms/Jo2_7000/annual-report. ${ }^{6}$ Or at least they are good at transposing directives. While directives require transposition, other EU law (e.g. regulations) is directly effective and does not require formal transposition by member states.
} 
observed Commission and ECJ action. When latent discrimination is high, there will be little action because it will be difficult to report infringements, and those being discriminated against may not even recognize the discrimination as such. As discrimination becomes easier to report, and societal definitions of discrimination more closely match those in the law, legal action should increase. Finally, where discrimination is low legal action should be as well because there are fewer cases to investigate.

Because we cannot measure the likelihood of a state to violate EU law by examining the number of observed violations, we attempt to uncover the relationship between likely violations and actual violations by looking at a particular directive in the area of labor law, namely the framework directive 89/391/EEC on the introduction of measures to encourage improvements in the safety and health of workers. This framework directive was adopted in 1989 and five related individual directives were adopted between 1989 and 1990. According to a Commission report in $2004,{ }^{7}$ EU15 states fell into three camps: those where transposition was rather difficult because it meant substantial change to national labor law (Greece, Ireland, Portugal, Spain, Italy, and Luxembourg), those states where transposition meant some change to national law (Austria, France, Germany, the United Kingdom, the Netherlands, and Belgium), and those states where the changes required were minimal (Denmark, Finland, and Sweden). Nevertheless, transposition and implementation raised Commission concern in all member states. The Commission report describes the transposition process in the EU15

\footnotetext{
${ }^{7}$ Communication from the Commission to the European Parliament, the Council, and the European Economic and Social Committee and the Committee of Regions on the Practical Implementation of the Provisions of Health and Safety at Work Directives 89/391(Framework), 89/654 (Workplaces), 89/655 (Work Equipment), 89/656 (Personal Protective Equipment), 90/269 (Manual Handling of Loads) and 90/270 (Display Screen Equipment). COM(2004)62 final.
} 
as slow. By 2004 the Commission had launched at least one infringement proceeding against every EU15 state, several of which led to ECJ cases, including cases against Germany, Austria, and France - countries with rather strong labor protection regimes.

\section{INSERT FIGURE 4 ABOUT HERE}

In contrast, there seems to have been surprisingly little difficulty in the postcommunist accession states. The transposition deadline for most post-communist enlargement countries fell shortly after their accession date. In all states implementing legislation was reported in a timely manner to the Commission and no post-communist state has experienced infringement proceedings with respect to the framework directive. Of course, it seems rather unlikely that labor protection in poorer post-communist countries is on par with countries like Germany and Austria. To measure the latent likelihood that a member state would land in court we employ two measures of workplace safety. First, we use International Labour Organization (ILO) data to examine the average annual rate of fatal injuries at work per 100,000 workers from 1999 to $2008 .^{8}$ Compared with non-fatal injuries, fatalities offer a better cross-national measure of workplace safety because fatalities are likely difficult to hide. While injury reporting (and even what qualifies as an injury) could vary across countries, cross-national variation is likely lower when reporting fatalities. Second, we examine workers' own perceived health risk on the job using the 2010 European Working Conditions Survey. Specifically, we use the percentage of respondents answering that they perceive a risk while at work. These two measures are moderately correlated at 0.4 . Sweden and Lithuania are both

\footnotetext{
${ }^{8}$ The Netherlands is dropped from all analyses using this variable as it is not included in the ILO data.
} 
outliers - Swedes perceive greater risk than we would expect based on fatality rates, while Lithuanians perceive less risk than we would expect. When these two countries are dropped, the correlation jumps to $0.59 .{ }^{9}$ If citizens in all member states were equally able to rely on EU law, countries with higher fatality rates and greater perceived risk should be subject to more court cases regarding 89/391/EEC. Instead we find the opposite. Figure 4 shows the relationship between our two measures of latent likelihood of violations of EU labor law and the number of ECJ cases concerning 89/391/EEC in which a member state has been a litigant. The correlation between fatalities and the number of ECJ cases is -0.25 and the correlation between perceived risk and ECJ cases is -0.36 . The figures clearly show that countries that go to court tend to be the ones in the midrange of perceived health risk and average fatality rate variables. Countries with the highest and lowest risks to workers tend not to go to court.

\section{INSERT TABLE 1 ABOUT HERE}

To further examine the relationship between the likelihood that a member state lands in the ECJ and these measures of latent risk of violations, we run several logit models. The dependent variable is binary, coded one if a member state faces one or more ECJ cases. We also include the log of member state population as a control, on the assumption that larger states are more likely to face court cases simply because they have more workers. ${ }^{10}$ Table 1 reports the results. The first two models include the ILO labor

\footnotetext{
${ }^{9}$ The ILO were downloaded from http://laborsta.ilo.org/, while the European Working Conditions Survey can be found at http://eurofound.europa.eu/ewco/surveys/.

${ }^{10}$ Of course, one could also run an OLS model. However, with a dependent variable that can only take on five categories, we clearly violate the underpinning OLS. Unfortunately,
} 
fatality rate as the main independent variable, while models 3-6 use the European Working Conditions Survey measure of perceived health risk. Models four and six exclude the outliers Sweden and Lithuania.

The coefficients on Labor Fatality Rate and Perceived Risk are negative across all models, and statistically significant (at the 0.1 level or higher) in models one, four, and six, while just barely missing the threshold for statistical significance in models one and three. Even after controlling for population size, those countries with higher latent risk are less likely to find themselves in court. To examine the substantive effects of the fatality rate on the likelihood of ending up in court, we calculate the change in the predicted likelihood of a court case when moving from the 25th percentile of Labor Fatality Rate to the 75 th percentile, holding the log of population at its mean (simulations are based on Model 2). This change results in an $18 \%$ reduction in the probability of facing a court case from $41 \%$ to $23 \%$. Simulations based on the other models yield similar results. Other models were run using the average number of infringements as the dependent variable, and again, the substantive results remained similar.

Now we present evidence for the theory in a country that has shown remarkable success in its transition to democracy. Lithuania is often held up as a success story in the transition from a Soviet republic to a liberal democracy, market economy, and EU member. It has neither experienced backsliding towards authoritarian tendencies like Hungary, nor egregious human rights abuses like Bulgaria or Romania (Conant 2014). After starting off at a quite low level, it now scores very well on a variety of World Bank Worldwide Governance Indicators (Kaufmann et al. 2010). More importantly, Lithuania

given the limited number of observations, it is not feasible to run an ordered logit, the most technically correct model for an ordinal dependent variable. 
has a stellar record - the best in the EU - when transposing EU law and avoiding infringements (Sedelmeier 2008; 2012).

In August 2012, elite level interviews were conducted in the Lithuanian Social Security and Labor Ministry, Environment Ministry, and Agriculture Ministry with bureaucrats knowledgeable about the transposition and implementation of EU law. Subjects were asked to describe the process of implementation in their particular area, what problems they encountered most frequently, and how implementation differed now and at the time of accession. These interviews provide evidence that the acquis were (and continue to be) difficult to implement due to a discrepancy between attitudes, norms and bureaucratic organization in the EU15 and the post-communist accession states, perhaps incentivizing creative compliance and advertising the lack of societal consensus.

Interviewees made clear that, first, they must frequently implement EU law that is not written with their country in mind, and second, it was much easier to transpose and implement the acquis at the time of accession than in recent years. Problems of the first type typically occur because regulations and directives that are appropriate for larger, older member states are oftentimes less appropriate for the new member states. Many legal acts that the new members must implement have been in existence long before they ever became members, meaning the new states were not part of the law-making process. Second, the new member states tend to be smaller and their delegations often feel they have little influence in the Council working group meetings where decisions about legislation are made. This is both a function of having less voting power and not being part of the networks forged by the older member states. ${ }^{11}$

${ }^{11}$ Personal interview, Lithuanian Social Security and Labor Ministry, August 6th, 2012. 
One particularly good example of a law that created unforeseen implementation problems in Lithuania comes from the area of agriculture. Rather than subsidize production, which often leads to significant market distortions, the EU Common Agriculture Policy provides support to farmers through direct payments based upon the amount of land in production. In the EU15, this is relatively unproblematic as most farmland is owned by farmers and has been farmed by the same families for generations. In the post-communist countries, this is not the case. Prior to the World War II and the Soviet occupation, a very high proportion of the Lithuanian population lived in rural areas and was involved in agriculture. During Soviet times, the farmland was collectivized and many people moved to cities to take non-agricultural jobs. With the fall of communism, many Lithuanians claimed ownership of land that their parents and grandparents had farmed prior to the Soviet occupation. However, the vast majority of these new landowners had no intention of returning to the farm. If they were willing to fill out some paperwork, and meet some minimal requirements (e.g. mowing the grass), they could qualify for EU direct payments, though. Many did, and have failed to comply even with the minimal requirements. Agricultural department audits have had to root out those individuals not meeting the requirements. But if the minimal requirements are met, there is nothing illegal about claiming payments. Because land ownership patterns differ significantly in the east and west, at least some direct payments were going to individuals who are not farmers at all. ${ }^{12}$ Because this policy was written without post-communist land ownership patterns in mind, rather than citizens viewing it as a mechanism for

\footnotetext{
${ }^{12}$ Personal interview, Lithuanian Agriculture Ministry, August 16th, 2012. The ministry was quick to note that most direct payments do go to actual farmers, who benefit tremendously from them.
} 
supporting farmers and protecting the countryside, it instead has created incentives for individuals to game the system, violating the spirit of the law, if not the law itself.

In addition, officials in the Agriculture Ministry pointed out that transposition and implementation on paper is different than implementation on the ground. Several programs were relatively easy to write into law, but much more difficult to explain to farmers. An official gave the example of animal payments system in which farmers are paid according to a weight classification scheme in which the carcass is weighted, as opposed the live animal. Farmers were reluctant to use the new scheme and industry officials had little incentive to inform the farmer about the new classification systems. ${ }^{13}$ This provides another example of a law placed on the books that was unlikely to lead to the creation of focal points.

Lastly, officials in all three ministries suggested that transposing the acquis into national law at the time of accession was relatively easy as there was near unanimous agreement that Lithuania needed to join the EU. Accession meant that certain tasks needed to be accomplished on time; accession agreement chapters needed to be closed. The parties were less likely to meddle around in the details, knowing that these changes were a condition for membership. An official in the Environment Ministry mentioned that Lithuania prided itself on being first in notifying transposition and implementation measures to the Commission among all 2004 accession states in the area of environment. ${ }^{14}$ As discussed earlier, the need to join the EU could have pushed politicians to pass laws without fully considering their applicability to the national

\footnotetext{
${ }^{13}$ Personal interview, Lithuanian Agriculture Ministry, August 16, 2012.

${ }^{14}$ Personal Interview, Lithuanian Environment Ministry, August 14th, 2012.
} 
context or level of support they would have in the general public, as perhaps was the case with the direct payments scheme for agriculture.

These data alone do not provide conclusive evidence of the mechanisms suggested by the theory. However, they do demonstrate the existence of the conditions necessary for enlargement to undermine the rule of law and suggest that more scholarly attention should be paid to this possibility.

\section{Conclusion}

While expansion of the European Union is certainly not viewed as universally positive, few studies focus on the potentially negative impact on the enlargement country. The theory presented here suggests that greater skepticism is warranted. Under certain conditions, the need to accept laws that a society is not ready to implement can lead to a cheapening of the meaning of law. The argument has implications for future EU expansion, as well as for organizations far beyond the EU. Within the EU it implies that future expansion to the Balkans and Turkey may not be wise for either the EU or the accession states. Outside the EU, it suggests a more difficult path for any international organization that hopes to pressure a non-member state towards greater respect for the rule of law simply by offering the "carrot" of membership coupled with strict policy conditionality.

It is also important to understand what this article is not arguing. It does not suggest that EU enlargement never leads accession states towards greater adherence to the rule of law. Nor it is meant to suggest that enlargement to the post-communist states of central and eastern Europe was "bad" policy. Certainly, many of these states have 
benefited substantially from EU membership — they have received structural funds to build roads, support to modernize agriculture, access to larger markets for their goods, and much more. Moreover, the model clearly highlights instances under which accession can lead to a deepening respect for the rule of law — namely, when a societal consensus exists, new EU law can create new focal points. The model, however, does caution against overly optimistic thinking when it comes to enlargement. The "transformative" power of the EU to instill democratic values in post-authoritarian countries may operate in ways we would not expect.

Acknowledgements: The article has greatly benefited from the comments of numerous scholars including Tanya Bagashka, Matt Gabel, Julia Gray, Alexandra Hennessy, Chris Jensen, Dan Kelemen, Ryan Kennedy, Will Phelan, Sven-Oliver Proksch, Lydia Tiede and several anonymous reviewers. Previous versions were presented at McGill University, University of Houston, University of Mannheim, University of Nevada, Las Vegas, and Washington University in St. Louis. I wish to thank Abdullah Aydogan for research assistance. Any remaining errors are my own. 


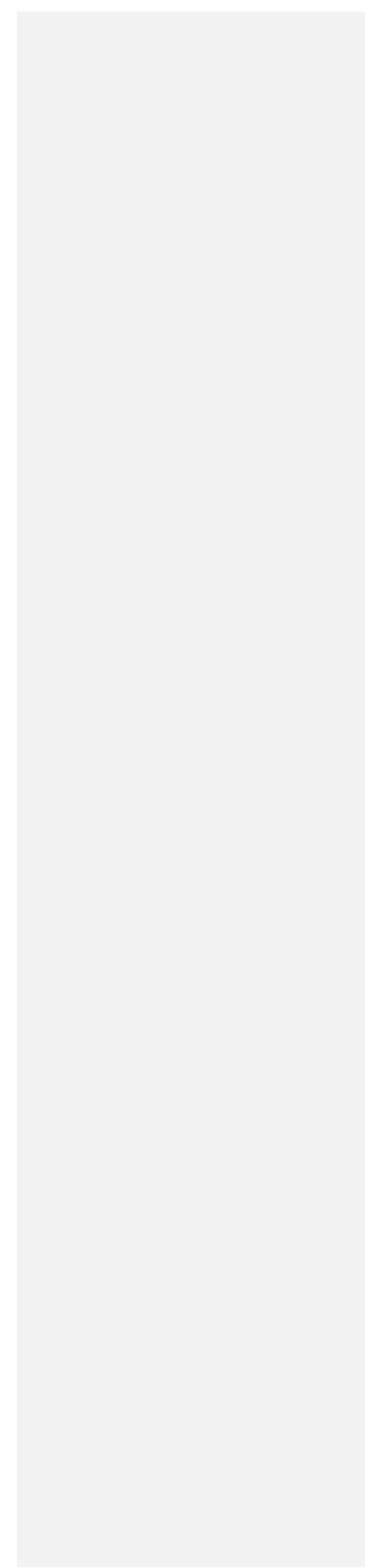




\section{References}

Berkowitz, Daniel, Katharina Pistor and Jean-Francois Richard (2003). 'Economic Development, Legality, and the Transplant Effect', European Economic Review, 47:1, 165-195.

Börzel, Tanja A. (2010). 'Why You Don’t Always Get What You Want: EU Enlargement and Civil Society in Central and Eastern Europe', Acta Politica, 45:1/2,1-10.

Cameron, David R. (2003). 'The Challenges of Accession', East European Politics and Societies, 17:1, 24-41.

Conant, Lisa (2014). 'Compelling Criteria? Human Rights in an Enlarging European Union', Journal of European Public Policy, 21:5, 713-729.

Cooter, Robert (1998). 'Expressive Law and Economics', Journal of Legal Studies, $27: S 2,585-607$.

Dimitrova, Antoaneta (2002). 'Enlargement, Institution-Building and the EU's Administrative Capacity Requirement', West European Politics, 25:4, 171-190.

Ekiert, Grzegorz (2008). 'Dilemmas of Europeanization: Eastern and Central Europe after the EU Enlargement', Acta Slavica Iaponica, 25, 1-28.

Falkner, Gerda, Oliver Treib and Elisabeth Holzleithner (2008). Compliance in the Enlarged European Union: Living Rights or Dead Letters? Surrey: Ashgate.

Finke, Daniel, Thomas König, Sven-Oliver Proksch and George Tsebelis (2012).

Reforming the European Union: Realizing the Impossible. Princeton: Princeton University Press.

Frey, Bruno S. (1997). ‘A Constitution For Knaves Crowds Out Civic Virtues', The Economic Journal, 107:443, 1043-1053. 
Gibbs, J.P. (1975). Crime, Punishment, and Deterrence. New York: Elsevier.

Goetz, Klaus H. (2000). 'European Integration and National Exectives: A Cause in Search of an Effect?', West European Politics, 23:4, 211-231.

Grabbe, Heather (2006). The EU's Transformative Power: Europeanization through Conditionality in Central and Eastern Europe. New York: Palgrave Macmillan.

Gray, Julia (2009). 'International Organization as a Seal of Approval: European Union Accession and Investor Risk', American Journal of Political Science, 53:4, 931949.

Grzymala-Busse, Anna and Abby Innes (2003). 'Great Expectations: The EU and Domestic Political Competition in East Central Europe', East European Politics and Societies, 17:1, 64-73.

Hafner-Burton, Emilie M. (2005). ‘Trading Human Rights: How Preferential Trade Agreements Influence Government Repression', International Organization, $59: 3,593-629$.

Jacoby, Wade (1999). 'Priest and Penitent: The European Union as a Force in the Domestic Politics of Eastern Europe', East European Constitutional Review, 8:1$2,62-67$.

Kaufmann, Daniel, Aart Kraay and Massimo Mastruzzi (2010). 'The Worldwide Governance Indicators: A Summary of Methodology, Data, and Analytical Issues', World Bank Policy Research Working Paper No. 5430.

Kelemen, R. Daniel and Terence Teo (2014). 'Law, Focal Points and Fiscal Discipline in the United States and the European Union', American Political Science Review, $108: 2,355-370$. 
Knight, Jack (1998). 'The Bases of Cooperation: Social Norms and the Rule of Law', The Journal of Institutional and Theoretical Economics, 154:4, 754-763.

König, Thomas and Thomas Bräuninger (2004). 'Accession and Reform of the European Union: A Game Theoretical Analysis of Eastern Enlargement and the Constitutional Reform', European Union Politics, 5:4, 419-439.

Linz, Juan J. and Alfred Stepan (1996). Problems of Democratic Transition and Consolidation. Baltimore: Johns Hopkins University Press.

McAdams, Richard H. (2000). 'A Focal Point Theory of Expressive Law', Virginia Law Review, 86:8, 1649-1729.

McBarnet, Doreen and Christopher Whelan (1991). 'The Elusive Spirit of the Law: Formalism and the Struggle for Legal Control', The Modern Law Review, 54:6, $848-873$.

Nonet, Philippe and Philip Selznick (2001). Law and Society in Transition: Toward Responsive Law. New Brunswick: Transaction Publishers.

Pistor, Katharina (2002). 'The Standardization of Law and Its Effect on Developing Economies', The American Journal of Comparative Law, 50:1, 97-130.

Posner, Eric A. (2000). 'Law and Social Norms: The Case of Tax Compliance', Virginia Law Review, 86:8, 1781-1819.

Pridham, Geoffrey (2005). Designing Democracy: EU Enlargement and Regime Change in Post-Communist Europe. New York: Palgrave Macmillan.

Reisinger, William M., Arthur H. Miller and Vicki L. Hesli (1995). 'Public Behavior and Political Change in Post-Soviet States', Journal of Politics, 57:4, 941-970. 
Rodriquez, Daniel B., Mathew D. McCubbins and Barry R. Weingast (2010). 'The Rule of Law Unplugged', Emory Law Journal, 59:6, 1456-1494.

Schelling, Thomas C. (1960). The Strategy of Conflict. Cambridge: Harvard University Press.

Schimmelfennig, Frank (2005). 'Strategic Calculation and International Socialization: Membership Incentives, Party Constellations, and Sustained Compliance in Central and Eastern Europe', International Organization, 59:4, 827-860.

Schimmelfennig, Frank and Hanno Scholtz (2008). 'EU Democracy Promotion in the European Neighbourhood: Political Conditionality, Economic Development, and Transnational Exchange', European Union Politics, 9:2, 187-215.

Schimmelfennig, Frank and Ulrich Sedelmeier (2004). 'Governance by Conditionality:

EU Rule Transfer to the Candidate Countries of Central and Eastern Europe', Journal of European Public Policy, 11:4, 669-687.

Schneider, Christina J. (2009). Conflict, Negotiation and European Union Enlargement. Cambridge: Cambridge University Press.

Sedelmeier, Ulrich (2008). 'After Conditionality: Post-Accession Compliance with EU Law in East and Central Europe', Journal of European Public Policy, 15:6, 806825.

Sedelmeier, Ulrich (2012). 'Is Europeanisation through Conditionality Sustainable? Lock-in of Institutional Change after EU Accession', West European Politics, $35: 1,20-38$. 
Slapin, Jonathan B. (2008). 'Bargaining Power at Europe's Intergovernmental

Conferences: Testing Institutional and Intergovernmental Theories', International Organization, 62:1, 131-162.

Slapin, Jonathan B. (2011). Veto Power: Institutional Design in the European Union.

Ann Arbor: University of Michigan Press.

Steuenberg, Bernard and Dimiter Toshkov (2009). 'Comparing Transposition in the 27

Member States of the EU: The Impact of Discretion and Legal Fit', Journal of

European Public Policy, 16:7, 951-970.

Sunstein, Cass R. (1996). 'Social Norms and Social Roles', Columbia Law Review, 96:4, 903-968.

Tittle, C.R. (1980). Sanction and Social Deviance: A Question of Deterrence. New York: Praeger.

Tyler, Tom R. (2006). Why People Obey the Law. Princeton: Princeton University Press. Vachudova, Milada A. (2008). 'Tempered by the EU? Political Parties and Party Systems before and after Accession', Journal of European Public Policy, 15:6, 861-879.

Vachudova, Milada A. (2005). Europe Undivided: Democracy, Leverage, and Integration After Communism. Oxford: Oxford University Press.

Whitehead, Laurence (2001). 'Democracy by Convergence: Southern Europe', in Laurence Whitehead (ed.), International Dimensions of Democratization. Oxford: Oxford University Press, 261-284.

Zielonka, Jan (2004). 'Challenges of EU Enlargement', Journal of Democracy, 15:1, 2235. 
Figure 1. Compliance Simulation: True Support High
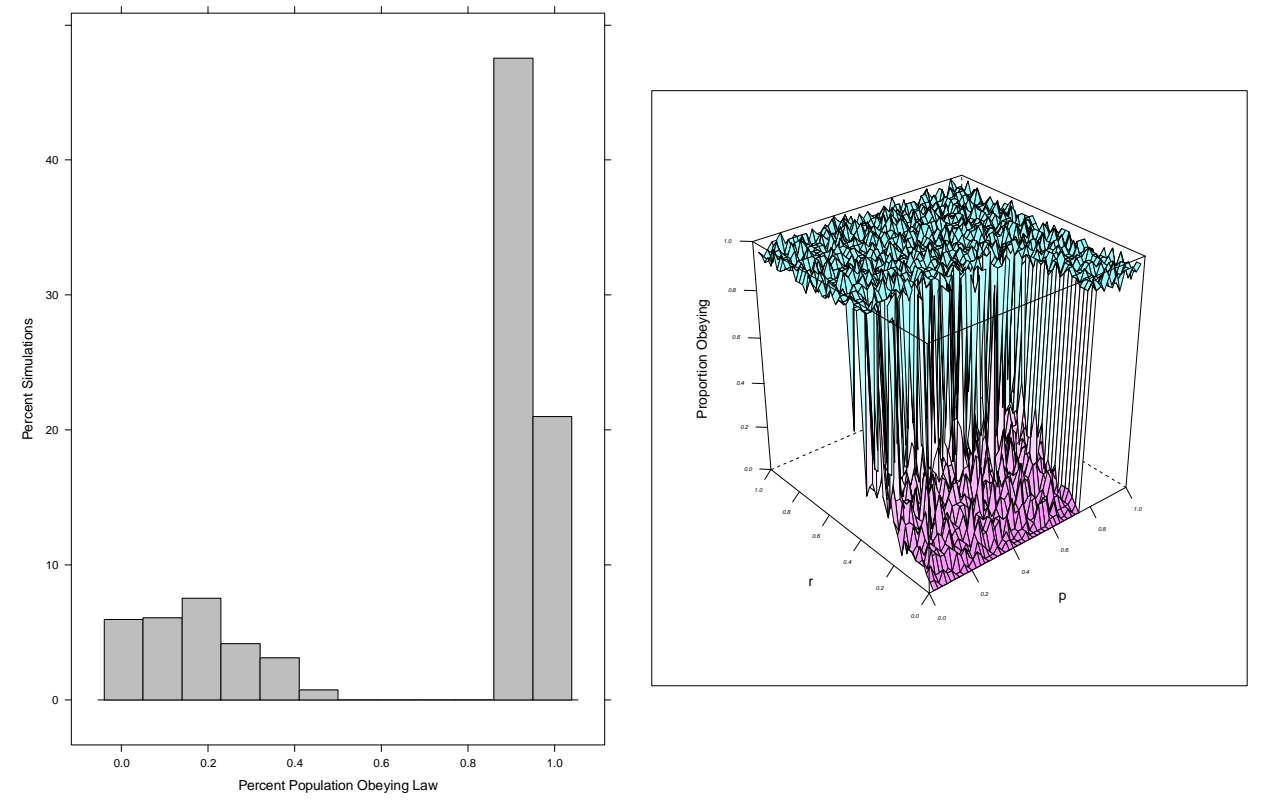
Figure 2. Compliance Simulation: True Support Low
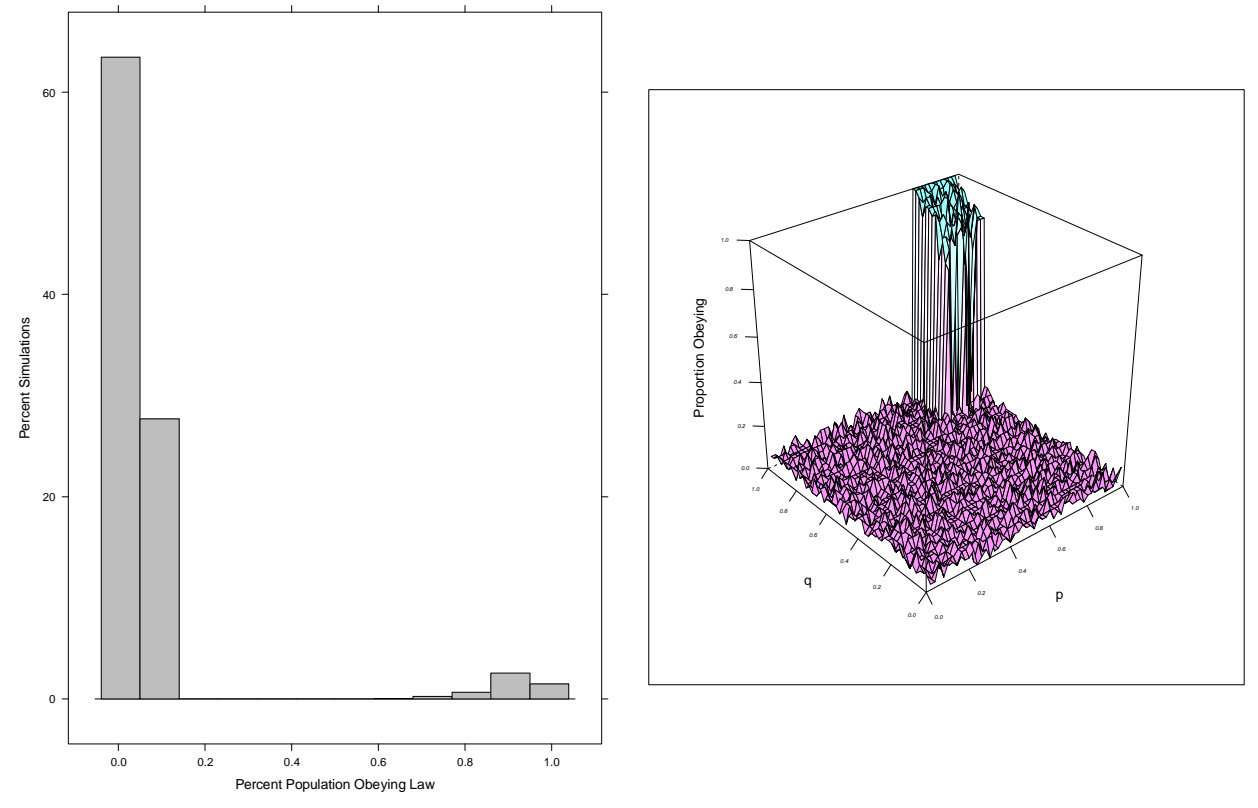
Figure 3. Compliance Simulation: True Support Moderate
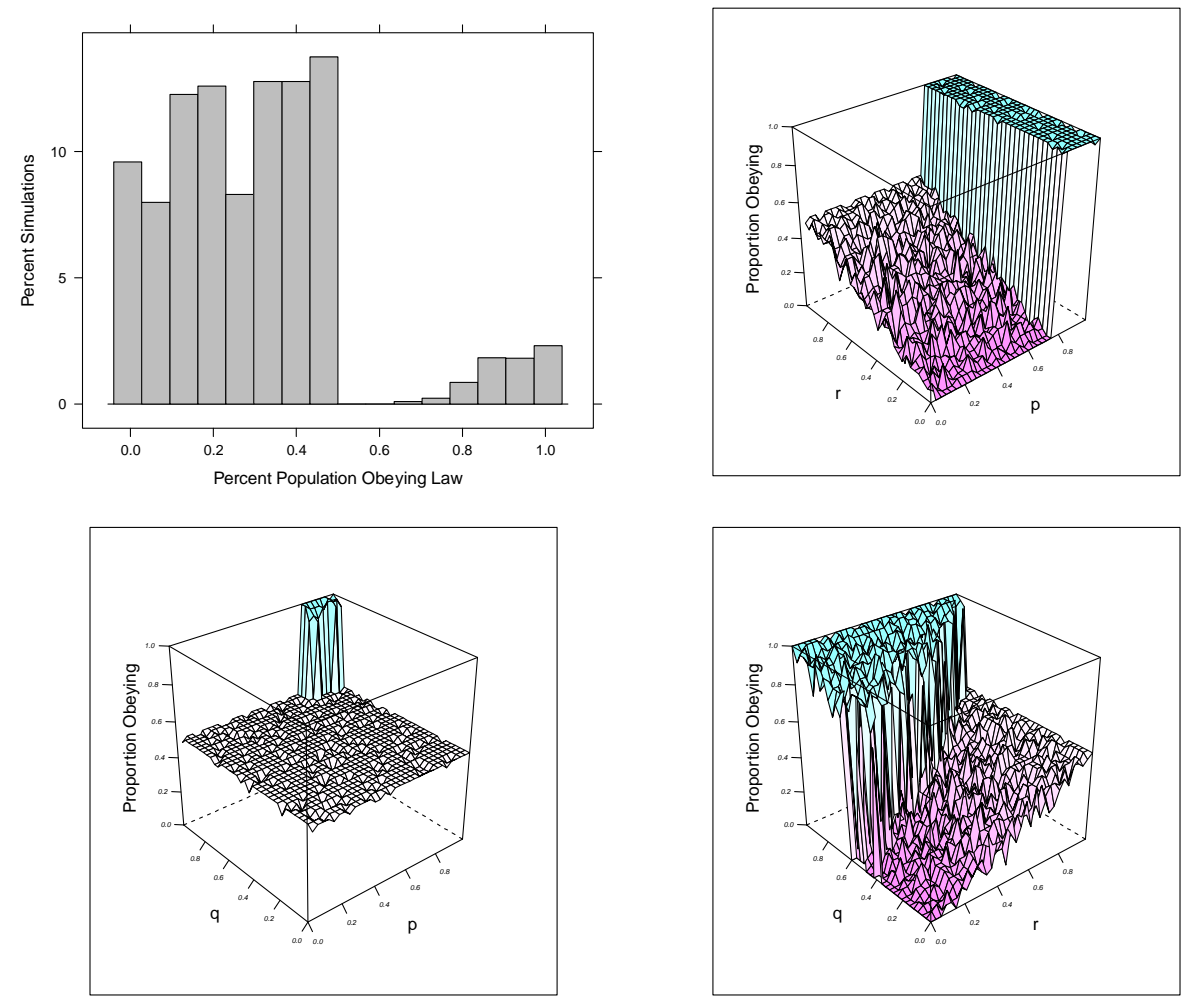
Figure 4: Number of ECJ Cases and Underlying Propensity to Violate EU Labor Law

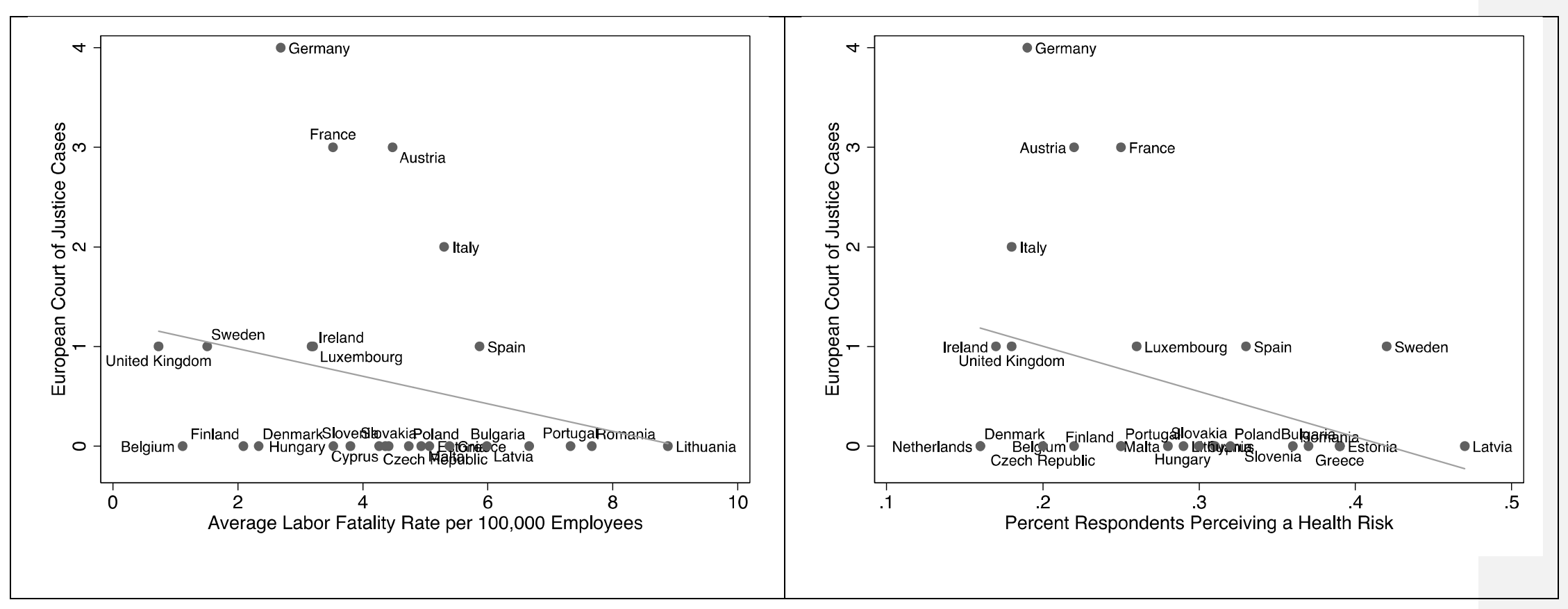


Table 1: Logit Models of the Likelihood that Member States Face an ECJ Case

\begin{tabular}{|c|c|c|c|c|c|c|}
\hline Variables & (1) & (2) & (3) & (4) & (5) & (6) \\
\hline Labor Fatality Rate & $\begin{array}{l}-0.44 * \\
(0.26)\end{array}$ & $\begin{array}{l}-0.43 \\
(0.27)\end{array}$ & & & & \\
\hline Perceived Risk & & & $\begin{array}{l}-8.63 \\
(5.60)\end{array}$ & $\begin{array}{c}-14.44 * * \\
(7.26)\end{array}$ & $\begin{array}{l}-6.15 \\
(5.83)\end{array}$ & $\begin{array}{c}-12.18 * \\
(7.34)\end{array}$ \\
\hline $\begin{array}{l}\text { Population } \\
\text { (logged) }\end{array}$ & & $\begin{array}{l}1.63 * \\
(0.92)\end{array}$ & & & $\begin{array}{c}1.37 \\
(0.88)\end{array}$ & $\begin{array}{c}1.27 \\
(0.96)\end{array}$ \\
\hline Constant & $\begin{array}{c}1.16 \\
(1.10)\end{array}$ & $\begin{array}{l}-10.27 \\
(6.47)\end{array}$ & $\begin{array}{c}1.65 \\
(1.52)\end{array}$ & $\begin{array}{c}2.97 \\
(1.82)\end{array}$ & $\begin{array}{l}-8.58 \\
(6.70)\end{array}$ & $\begin{array}{l}-6.53 \\
(7.23)\end{array}$ \\
\hline $\begin{array}{l}\text { Log-Likelihood } \\
\text { Observations }\end{array}$ & $\begin{array}{c}-15.01 \\
26\end{array}$ & $\begin{array}{c}-12.93 \\
26\end{array}$ & $\begin{array}{c}-15.81 \\
27\end{array}$ & $\begin{array}{l}-12.95 \\
25\end{array}$ & $\begin{array}{c}-14.35 \\
27\end{array}$ & $\begin{array}{c}-11.89 \\
25\end{array}$ \\
\hline
\end{tabular}

